\title{
Author Correction: NFAT primes the human RORC locus for RORyt expression in CD4+T cells
}

\author{
Hanane Yahia-Cherbal, Magda Rybczynska, Domenica Lovecchio (1D, Tharshana Stephen, Chloé Lescale, \\ Katarzyna Placek, Jérome Larghero, Lars Rogge (D) \& Elisabetta Bianchi (i)
}

Correction to: Nature Communications https://doi.org/10.1038/s41467-019-12680-x, published online 16 October 2019.

The original version of this Article contained an error in the author affiliations.

Affiliation 4 incorrectly read 'Institut Pasteur, Departments of Immunology and Genomes and Genetics, Paris, France'. The correct affiliation 4 should read as 'Institut Pasteur, Genome Integrity, Immunity and Cancer Unit, Equipe Labellisée Ligue Contre le Cancer, Department of Immunology, Department of Genomes and Genetics, Paris, France'.

This has now been corrected in both the PDF and HTML versions of the Article.

Published online: 26 November 2019

\begin{abstract}
(c) Open Access This article is licensed under a Creative Commons Attribution 4.0 International License, which permits use, sharing, adaptation, distribution and reproduction in any medium or format, as long as you give appropriate credit to the original author(s) and the source, provide a link to the Creative Commons license, and indicate if changes were made. The images or other third party material in this article are included in the article's Creative Commons license, unless indicated otherwise in a credit line to the material. If material is not included in the article's Creative Commons license and your intended use is not permitted by statutory regulation or exceeds the permitted use, you will need to obtain permission directly from the copyright holder. To view a copy of this license, visit http://creativecommons.org/licenses/by/4.0/.
\end{abstract}

(C) The Author(s) 2019 